\title{
Preparation and Characterization of Impregnated Magnetic Particles on Oil Palm Frond Activated Carbon for Metal Ions Removal
}

(Penyediaan dan Pencirian Zarah Magnet Terjejal ke atas Pelepah Kelapa Sawit Karbon Aktifan untuk Penyingkiran Ion Logam)

\author{
MuZAKKIR MOHAMmad ZAInOL, NOR AishaH SAIDINA AMIN* \& MOHD ASMAdi
}

\begin{abstract}
The magnetic adsorbents i.e. oil palm frond-magnetic particles (OPF-MP) and oil palm frond activated carbon-magnetic particles (OPFAC-MP) have been prepared by impregnation of iron oxide via co-precipitation method. The magnetic adsorbents and their parent materials were characterized using Fourier transform infrared (FTIR), thermogravimetric analysis (TGA), field emission scanning electron microscopy (FESEM), Brunauer Emmett Teller (BET), Barrett, Joyner $\&$ Halenda (BJH) and t-plot method, $x$-ray diffraction (XRD) and also using vibrating sample magnetometry (VSM) to study their properties and surface chemistry. The activated carbon magnetic adsorbent confers high surface area of 700 $\mathrm{m}^{2} / \mathrm{g}$ with amorphous structure and magnetic properties of $2.76 \mathrm{emu} / \mathrm{g}$. The OPF-MP and OPFAC-MP were then applied in adsorption study for ions removal of $\mathrm{Pb}(\mathrm{II}), \mathrm{Zn}(\mathrm{II})$ and $\mathrm{Cu}(\mathrm{II})$. OPFAC-MP has shown high removal efficiency of $100 \%$ with adsorption capacity up to $15 \mathrm{mg} / \mathrm{g}$ of $\mathrm{Pb}(\mathrm{II}), \mathrm{Zn}(\mathrm{II})$ and $\mathrm{Cu}(\mathrm{II})$ ions compared to OPF-MP. In addition, the magnetic adsorbents were also compared with their parent materials to observe the effect of magnetic particles. Accordingly, the impregnation of magnetic particles enhances the metal ions adsorption comparing to their parent materials.
\end{abstract}

Keywords: Activated carbon; adsorption; magnetic particle; metal ions; oil palm frond

\section{ABSTRAK}

Bahan penjerap magnet iaitu zarah magnet pelepah kelapa sawit (OPF-MP) dan zarah magnet pelepah kelapa sawit zarah karbon aktifan (OPFAC-MP) telah disediakan dengan menjejal besi oksida melalui kaedah pemendakan bersama. Bahan penjerap magnet dan bahan induknya telah dicirikan menggunakan transformasi Fourier inframerah (FTIR), analisis termogravimetri (TGA), mikroskop elektron imbasan pancaran medan (FESEM), Brunauer Emmett Teller (BET), Barrett, Joyner \& Halenda (BJH) dan kaedah t-plot, pembelauan sinar-x (XRD) dan juga menggunakan sampel magnetometri bergetar (VSM) untuk mengkaji sifat dan permukaan kimianya. Bahan penjerap magnet karbon aktifan menganugerahkan kawasan permukaan tinggi seluas $700 \mathrm{~m}^{2} / \mathrm{g}$ dengan struktur amorfus dan sifat magnet $2.76 \mathrm{emu} / \mathrm{g}$. OPF-MP dan OPFAC$M P$ kemudiannya digunakan dalam kajian penjerapan untuk penyingkiran ion $\mathrm{Pb}(\mathrm{II}), \mathrm{Zn}(\mathrm{II})$ dan $\mathrm{Cu}(\mathrm{II})$. OPFAC-MP telah menunjukkan kecekapan penyingkiran tinggi sebanyak 100\% dengan kapasiti penjerapan sehingga 15 mg/g untuk ion $\mathrm{Pb}(\mathrm{II}), \mathrm{Zn}(\mathrm{II})$ dan $\mathrm{Cu}(\mathrm{II})$ berbanding OPF-MP. Di samping itu, bahan penjerap magnet juga telah dibandingkan dengan bahan induknya untuk memerhatikan kesan zarah magnet. Sehubungan dengan itu, zarah magnet terjejal meningkatkan penjerapan ion logam berbanding bahan induknya.

Kata kunci: Ion logam; karbon; magnet zarah; pelepah kelapa sawit; penjerapan

\section{INTRODUCTION}

Magnetic particles have become an attention in research work and attracted many researchers due to their wide applications. The area of applications of magnetic particles or modified magnetic particles includes as catalyst or catalyst support (Ding et al. 2006; Gill et al. 2007; Hu et al. 2011; Koukabi et al. 2012; Liu et al. 2010), adsorbent (Liao \& Chen 2002; Oliveira et al. 2002; Simeonidis et al. 2011; Wang et al. 2010; Yao et al. 2012; Zainol et al. 2014) and especially in medical application like drug delivery (Chertoka et al. 2008), diagnosis and therapy (Hua et al. 2010; Mornet et al. 2004; Rudge et al. 2000; Rudolf et al. 2006) and DNA (Perez et al. 2002; Stoeva et al. 2005). The modification of material with magnetic particles seems to be useful for improving related applications and creating a new research field by exploring their potentials including in the waste-water treatment. The synthesis of superparamagnetic materials provides a significant progress toward separation technology where external magnetic field is applied to magnetize the material to be separated from other compounds. Due to the flexible function of magnetic particles, the particles can be impregnated into other materials to produce magnetic adsorbent for the separation and treatment process.

Many treatment methods were applied to remove inorganic and organic materials from wastewater. The inorganic materials usually dissolve in wastewater and required a suitable method for treatment. Inorganic 
pollutants like heavy metal, many efforts have been done to remove this material from wastewater since the metal released give a negative effect to the environment and life health. Precipitation or ion exchange method are reliable for better recovery of metallic ions in industrial application (Bulut \& Tez 2007). However, the precipitation method requires large settling tanks for precipitated sludge and more suitable for the removal of organic compound. As for ion exchange method, the application is limited due to high cost of operation. Besides, subsequent processes are required for treatment via precipitation method and new technologies for ion exchange may increase the overall operation cost.

Among the physiochemical treatment methods available, adsorption becomes one of the applications that offers high efficiency, cost effective and easy handling process (Panneerselvam et al. 2011). Previously, the adsorption was applied in dyes removal (AbdurRahman et al. 2013; Chia et al. 2013; Hashemian et al. 2013; Malik 2004), metal ions (Ge et al. 2012; Guo et al. 2008; Yaacob \& Samsudin 2007; Zainol et al. 2014) and chemicals (Alam et al. 2007; Vu et al. 2015; Yao et al. 2014). As for metal ions, suitable adsorbent are needed to apply for removal and activated carbon is commonly used in metal ion removal such as $\mathrm{Pb}, \mathrm{Zn}$ and $\mathrm{Cu}$. Activated carbon products from biomass have the potentials applications such as adsorbent in water pollution control because of their high specific surface area and porosity, extensive adsorption capacity and surface functional groups (Gao et al. 2013). Previously, there are some research works on modification of adsorbent with magnetic particles for heavy metal ions removal (Chang \& Chen 2005; Donia et al. 2012; Ge et al. 2012; Zainol et al. 2014). The modification with magnetic particles was practically to improve their capability and application at separation stage. In our previous work, the oil palm shell activated carbon was modified with magnetic particles and the result shows the capability of magnetic adsorbent in removing the metal ions (Zainol et al. 2014). The magnetic adsorbent obtained high removal as compared to the parent material. The modified adsorbents with magnetic particles gave good opportunity to improve the treatment process and better handling in separation of adsorbent from the wastewater.

In this work, the oil palm frond was used to prepare activated carbon. Subsequently, the oil palm frond activated carbon was modified through impregnation with magnetic particles that was synthesized via co-precipitation method. The resultant oil palm frond activated carbon (OPFAC) and oil palm frond activated carbon magnetic particles (OPFACMP) were characterized using Fourier transform infrared (FTIR), thermogravimetric analysis (TGA), field emission scanning electron microscopy (FESEM), BET, BJH and t-plot method, X-ray diffraction (XRD) and also using vibrating sample magnetometry (VSM). Finally, OPFAC and OPFACMP were further tested for removal of metal ions and the performance and potential of both samples in adsorption process were observed.

\section{EXPERIMENTAL DETAILS}

\section{MATERIALS}

Oil palm frond (OPF) was obtained from Malaysian Palm Oil Board (MPOB), Malaysia and the whole OPF were consisted of leaflets and petiole. Lead nitrate $\left(\mathrm{Pb}\left(\mathrm{NO}_{3}\right)_{2}\right)$, copper (II) nitrate trihydrate $\left(\mathrm{Cu}\left(\mathrm{NO}_{3}\right)_{2} \cdot 3 \mathrm{H}_{2} \mathrm{O}\right)$, zinc nitrate hexahydrate $\left(\mathrm{Zn}\left(\mathrm{NO}_{3}\right)_{2} \cdot 6 \mathrm{H}_{2} \mathrm{O}\right)$, iron (II) sulfate heptahydrate $\left(\mathrm{FeSO}_{4} .7 \mathrm{H}_{2} \mathrm{O}\right)$, iron (III) chloride hexahydrate $\left(\mathrm{FeCl}_{3} \cdot 6 \mathrm{H}_{2} \mathrm{O}\right)$, ammonium hydroxide $\left(\mathrm{NH}_{4} \mathrm{OH}, 28-30 \%\right)$, sodium hydroxide $(\mathrm{NaOH})$, acid hydrochloric $(\mathrm{HCl}, 95-$ $97 \%)$, potassium carbonate $\left(\mathrm{K}_{2} \mathrm{CO}_{3}\right)$ and sodium chloride $(\mathrm{NaCl})$ were mainly purchased from $\mathrm{QRec}, \mathrm{New}$ Zealand as guaranteed grades. $\mathrm{Pb}\left(\mathrm{NO}_{3}\right)_{2}, \mathrm{Cu}\left(\mathrm{NO}_{3}\right)_{2} .3 \mathrm{H}_{2} \mathrm{O}$ and $\mathrm{Zn}\left(\mathrm{NO}_{3}\right)_{2} \cdot 6 \mathrm{H}_{2} \mathrm{O}$ were used in preparing the metal ions solution.

\section{ACTIVATED CARBON FROM OIL PALM FROND (OPFAC)}

Table 1 summarizes the chemical composition of OPF. OPF was used to prepare activated carbon for heavy metal adsorption. Two stage of activation processes were conducted to utilize OPF in preparing OPFAC was followed by Chen et al. (2011) with some modification on the method. OPF was grinded and sieved for particles size less than $0.5 \mathrm{~mm}$. After sieving, the OPF was pre-carbonized using Carbolite tube furnace at $450^{\circ} \mathrm{C}$ for $1 \mathrm{~h}$ under inert atmosphere as the first stage activation process.

In the second stage, $7 \mathrm{~g}$ of the pre-carbonized OPF was mixed with $\mathrm{K}_{2} \mathrm{CO}_{3}$ solution (1:1 w/w in $9 \mathrm{~mL}$ of distilled water) for $24 \mathrm{~h}$ under constant stirring (200 rpm). This method was according to the study done by Gurten et al. (2012). The mixture was filtrated and the solid part was dried at $105^{\circ} \mathrm{C}$ for $24 \mathrm{~h}$. The product was further carbonized using the same furnace at $800^{\circ} \mathrm{C}\left(20^{\circ} \mathrm{C} / \mathrm{min}\right)$ for $1 \mathrm{~h}$ with nitrogen flow of $80 \mathrm{~cm}^{3} / \mathrm{min}$. Then, the carbonized OPF was repeatedly washed with hot distilled water $\left(\sim 60^{\circ} \mathrm{C}\right)$ to remove excess chemical. The washing step was repeated until the $\mathrm{pH}$ value of the washed solution was around 6 to 7 . Finally, OPF activated carbon (OPFAC) was dried at $105^{\circ} \mathrm{C}$ for $24 \mathrm{~h}$.

\section{PREPARATION OF OPF-MP AND OPFAC-MP}

The magnetic particles (MP) were synthesized and impregnated on parent materials (OPF and OPFAC) to produce magnetic adsorbent. Co-precipitation method was used in synthesizing MP from $\mathrm{Fe}^{2+} / \mathrm{Fe}^{3+}$ solution in alkaline media under inert atmosphere as studied by Panneerselvam et al. (2011). During the reaction, the nitrogen was continuously flow $\left(80 \mathrm{~cm}^{3} / \mathrm{min}\right)$ to avoid the presence of air inside the flask. A solution of $\mathrm{Fe}^{2+} / \mathrm{Fe}^{3+}$ with molar ratio of 0.5 was prepared and stirred $(200 \mathrm{rpm})$ in $80 \mathrm{~mL}$ of deionized water and heated until the temperature reached $80^{\circ} \mathrm{C}$. Then, $10 \mathrm{~mL}$ of ammonium hydroxide was added slowly to precipitate the solution. Based on the stoichiometry equation of the magnetic adsorbent production by Panneerselvam et al. (2011), $10 \mathrm{~g}$ of sample 
TABLE 1. Chemical composition of oil palm frond (wt.\%, dry basis composition based on TGA)

\begin{tabular}{lcccc}
\hline OPF Contents & Cellulose & Hemicellulose & Lignin & Others \\
\hline Composition (wt. \%) & 44.15 & 29.07 & 21.16 & 5.62 \\
\hline
\end{tabular}

waste was added directly to the precipitate to ensure the growth of the magnetic particle on the sample precursor. The reaction condition was maintained under constant stirring for $30 \mathrm{~min}$. The resulting magnetic adsorbents (OPF-MP and OPFAC-MP) were cooled down and washed repeatedly with distilled water to remove excess chemical. The washed solution was tested until the $\mathrm{pH}$ value is around 6 to 7 . Then, solid products were dried under vacuum at $80^{\circ} \mathrm{C}$ for $4 \mathrm{~h}$. OPF and OPF-MP was used as controller for comparison with OPFAC and OPFAC-MP, respectively.

\section{CHARACTERIZATION OF OPF-MP AND OPFAC-MP}

Detection of chemical bonding for the adsorbent was studied using FTIR (Perkin-Elmer Spectrum) using $\mathrm{KBr}$ pellet for IR range of $400-4000 \mathrm{~cm}^{-1}$ and the spectra obtained were further analyzed. The thermal stability of parent materials and modified adsorbents were determined using TGA (Perkin Elmer TGA 7) from 30 to $900^{\circ} \mathrm{C}$ under nitrogen flow at $10^{\circ} \mathrm{C} / \mathrm{min}$. In addition, TGA was used to determine main composition of OPF. The morphology of sample product was observed at $1000 \times, 10 \mathrm{kV}$ by using FESEM (ZEISS Supra 35VP with GEMINI column). The surface area, pore size and volume were evaluated using Micromeritics MicroActive 2.00 instrument according to standard nitrogen adsorption and desorption at $77 \mathrm{~K}$. The BET was used to measure the surface area of products while the t-plot and BJH methods were used to estimate the distribution of micropores and mesopores, respectively. XRD analysis was evaluated using a Bruker D8 Advance diffractometer system $(\mathrm{Cu} \mathrm{K}$ radiation, $40 \mathrm{kV}, 30 \mathrm{~mA})$ for angle $2 \theta$ between $10^{\circ}$ and $80^{\circ}$. Additional analysis was done on the magnetic adsorbent using VSM (Lake Shore 7400) to study the magnetization value and hysteresis loop of the product.

\section{ADSORPTION OF METAL IONS}

Zero point charge $\left(\mathrm{pH}_{\mathrm{zpc}}\right)$ for magnetic adsorbents was determined by preparing $0.01 \mathrm{M} \mathrm{NaCl}$ solution $(50 \mathrm{~mL})$ in conical flasks with a different $\mathrm{pH}$ in the range of 2-12 (Panneerselvam et al.2011). Then, $0.25 \mathrm{~g}$ of adsorbent was added into solutions for each flask and retained for $48 \mathrm{~h}$. The initial and final $\mathrm{pH}$ was measured using $\mathrm{pH}$ meter and finally graph plotted for $\mathrm{pH}_{\text {final }}$ versus $\mathrm{pH}_{\text {initial }}$.

As for adsorption studies, $\mathrm{Pb}\left(\mathrm{NO}_{3}\right)_{2}, \mathrm{Zn}\left(\mathrm{NO}_{3}\right)_{2} .6 \mathrm{H}_{2} \mathrm{O}$, and $\mathrm{Cu}\left(\mathrm{NO}_{3}\right)_{2} \cdot 3 \mathrm{H}_{2} \mathrm{O}$ were dissolved in distilled water to prepare a stock solution of $30 \mathrm{mg} / \mathrm{L}$ of $\mathrm{Pb}$ (II), $\mathrm{Zn}$ (II) and $\mathrm{Cu}$ (II), respectively. $50 \mathrm{~mL}$ of metal ions solution at $\mathrm{pH} 2$ to 10 (adjusted by adding $\mathrm{NaOH}$ or $\mathrm{HCl}$ and measured using $\mathrm{pH}$ meter) was used for batch adsorption process at room temperature for $30 \mathrm{~min}$ with adsorbent dosage of 0.1 $\mathrm{g}$ and $0.15 \mathrm{~g}$ for OPF-MP and OPFAC-MP, respectively. The concentration of metal ions was analyzed using atomic adsorption spectroscopy (AAS).

\section{RESULT AND DISCUSSION}

\section{CHARACTERIZATION OF OPF-MP AND OPFAC-MP}

Fourier transforms infrared (FTIR) spectroscopy The functional groups and bonding structures of all samples were studied through infrared spectra as shown in Figure 1. The existence frequency peak of C-O stretching for parent materials (OPF and OPFAC) were detected around $1000-1200 \mathrm{~cm}^{-1}$ represented the structure of lignin. This peak also represents functional group in holocellulose (hemicellulose and cellulose) structure of OPF. Based on the review by $\mathrm{Xu}$ et al. (2013), the wavenumber for C-O functional group around $1000-1200 \mathrm{~cm}^{-1}$ was related to the lignin and holocellulose structure. Poljanšek and Krajnc (2005) reported the frequency of C-O stretching detected was around $1157 \mathrm{~cm}^{-1}$. The sharp frequency peak of C-O stretching for OPF and OPF-MP were observed and the peak was reduced for OPFAC and OPFAC-MP due to the decomposition of organic compound such as hemicellulose and cellulose affected by carbonization. The small frequency detected around 750 to $1000 \mathrm{~cm}^{-1}$ for $\mathrm{C}-\mathrm{C}$ bonding in the all samples structure within the range. Figure 1(a) and 1(b) shows broad frequency peak of -OH group around $3300 \mathrm{~cm}^{-1}$, aliphatic C-H group around 2925 $\mathrm{cm}^{-1}$, detection of $\mathrm{C}=\mathrm{O}$ vibration band (amide group) around $1630 \mathrm{~cm}^{-1}$, weak intensity of $-\mathrm{SO}_{3}$ stretching at $1225 \mathrm{~cm}^{-1}$ and the stretching around $1725 \mathrm{~cm}^{-1}$. These frequencies could be attributed to the carbonyl stretching of carboxyl (Panneerselvam et al. 2011). The weak frequency peak was detected for the C-N stretching between 1180 and $1360 \mathrm{~cm}^{-1}$. As for OPFAC in Figure 1(e), the small intensity of $\mathrm{O}-\mathrm{H}$ stretching vibration was detected around 3300 $\mathrm{cm}^{-1}$ due to reduction of hydroxyl group after activation. This explained the formation of amorphous phase carbon structure after the activation (Gao et al. 2013).

By comparing the parent's with the impregnated materials, new frequency peaks were detected in the spectrum. For OPFAC-MP, the broad frequency peak for O-H stretching vibration (3500-3300 $\mathrm{cm}^{-1}$ ) was assigned to the functional group on the surface of magnetite. This frequency peak was also detected for OPF-MP, however, the peak of -OH group of surface magnetic particles was along with strong broad band of -OH in OPF. Besides, the magnetic adsorbent (OPF-MP and OPFAC-MP) show detection 


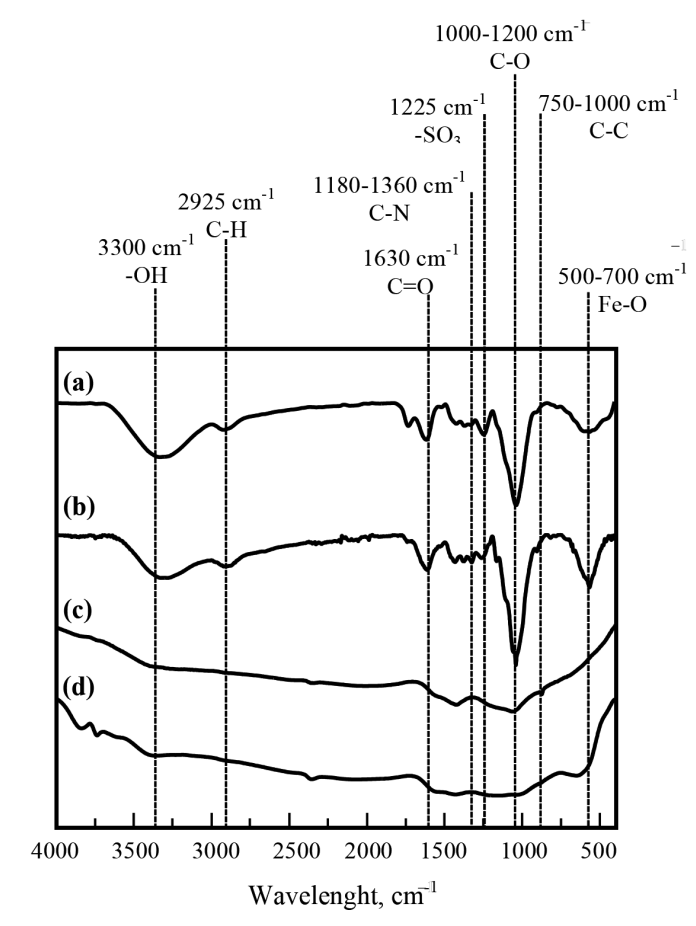

FIGURE 1. FTIR spectra of (a) OPF, (b) OPF-MP, (c) OPFAC and (d) OPFAC-MP

of new peak around 500 to $700 \mathrm{~cm}^{-1}$ that refers to $\mathrm{Fe}-\mathrm{O}$ bonding after impregnation of magnetic particles. These two significant frequencies were related to the functional group of magnetic particle on the surface of parent material which involves the metal binding with the material structure.

Thermogravimetric analysis (TGA) Thermal gravimetric (TG) and derivative thermal gravimetric (DTG) curves of parent materials and magnetic adsorbents are depicted in Figure 2. Based on DTG peak, the initial loss was observed around $100^{\circ} \mathrm{C}$ indicated the volatilization of the sample moisture. For OPF and OPF-MP samples (Figure 2(b)), the high decomposition was observed around 200 to $400^{\circ} \mathrm{C}$ is referred to the decomposition of cellulose and hemicelluloses. Mass losses of the samples were also observed at temperature $\geq 800^{\circ} \mathrm{C}$ represented the decomposition of lignin compound. The slow weight reduction of OPFAC and OPFAC-MP were shown above $200^{\circ} \mathrm{C}$ and about $70-75$ wt. \% of the sample can be hold up to $900^{\circ} \mathrm{C}$. Accordingly, the carbonization of the sample was caused high weight composition of carbon due to the decomposition of other organic compound. Their thermal stability was increased and show low weight decomposition at high temperature above $200^{\circ} \mathrm{C}$. Thus, the activated carbon such as OPFAC has shown a good thermal stability compared to biomass material (OPF).

The impregnation by magnetic particles also shows an effect on the stability of the magnetic adsorbents. As for TG curve, impregnated sample has small difference in weight loss compare to parent materials. The weight differences were about 2-5 wt. $\%$ between parent and impregnated samples in the temperature range 200 to $850^{\circ} \mathrm{C}$. Based on the results, the impregnation of parent materials with magnetic particles increased the thermal stability of sample as the percentage of weight losses reduced.

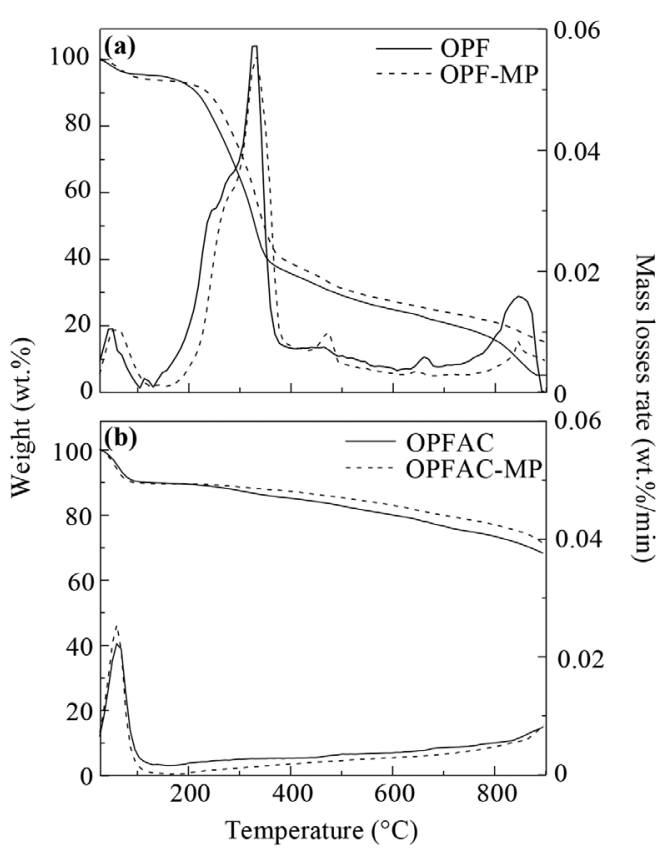

FIGURE 2. TG-DTG curves of (a) OPF and OPF-MP, and (b) OPFAC and OPFAC-MP

Morphology Study via FESEM The FESEM images of parent materials and magnetic adsorbents are shown in Figure 3. Figure 3(a) and 3(c) shows the surface images of OPF and OPFAC, respectively. The surface of OPFAC shows the differences of morphology structure compared to OPF sample. The porous structure was formed on the surface affected by chemical activation process. Furthermore, the surface morphology of magnetic adsorbent was observed and their differences between the parent adsorbents were compared. The magnetic adsorbents were shows high dispersion of magnetic particles on their surface (Figure $3(b)$ and 3(d)). The white layer obtained through FESEM images is referred to the dispersion of magnetic particles on the surface of material. Thus, it is confirmed that the magnetic particles was successfully impregnated on the surface of OPF and OPFAC.

Surface Area and Pore Analysis The $\mathrm{N}_{2}$ adsorption and desorption isotherms of parent materials and magnetic adsorbents are shown in Figure 4. The isotherm has influence by type I at the initial step region of adsorption $(<0.05$ relative pressure) for OPFAC and OPFAC-MP (Figure 4(a)). The strong adsorption was obtained due to the existence of micropores structure. The OPF and OPF-MP (Figure 4(b)) shows no existence of micropores structure. Based on Figure 4(a) and 4(b), the approximate location of monolayer formation was occurs around 
Parent material

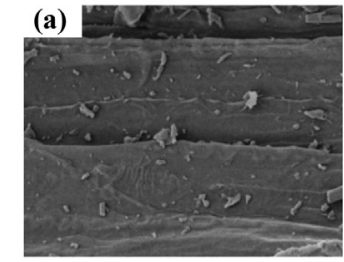

$\mathrm{OPF}$

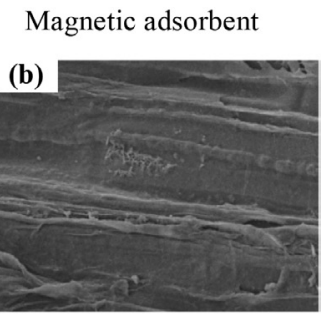

OPFAC
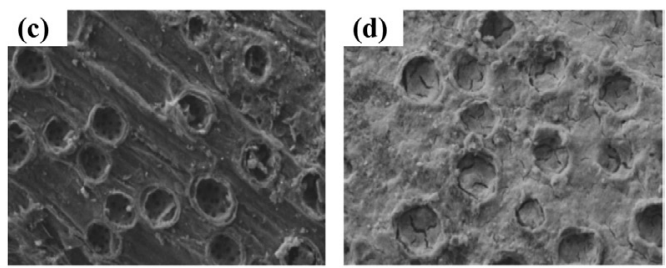

FIGURE 3. FESEM images of (a) OPF, (b) OPF-MP, (c) OPFAC, and (d) OPFAC-MP at $1000 \times, 10 \mathrm{kV}$

0.05 to 0.3 relative pressure. The plot shows low slope region in the middle of isotherm related to the first few multilayers formation. Above relative pressure of 0.5, there is formation of hysteresis that indicates capillary condensation in mesopores of samples. Thus, all samples of adsorbents have a formation of mesoporous structure based on the hysteresis loop in the figure. Accordingly, the surface area and pores of OPFAC and OPFAC-MP have influence by micropores and mesoporous structure, while for OPF and OPF-MP their structure were contributed by mesopores formation. The overall isotherms distribution was classified as a type IV which related to the formation of mesoporous material.

Table 2 presents the results of the surface area, pore volume and pore diameter of parent materials and magnetic adsorbents. Activated carbons have shown high surface area with high micropores and mesopores. The prepared OPFAC has total surface of $440 \mathrm{~m}^{2} / \mathrm{g}$ with $368 \mathrm{~m}^{2} / \mathrm{g}$ of micropores and $72 \mathrm{~m}^{2} / \mathrm{g}$ of mesopores. In contrast, OPF was shown low mesopores surface area $\left(1.91 \mathrm{~m}^{2} / \mathrm{g}\right)$ and the activation of OPF to prepare OPFAC has significantly increased their surface area.

The surface area of magnetic adsorbents increased after impregnation. Usually impregnation of magnetic particles reduce the surface area of the parent materials

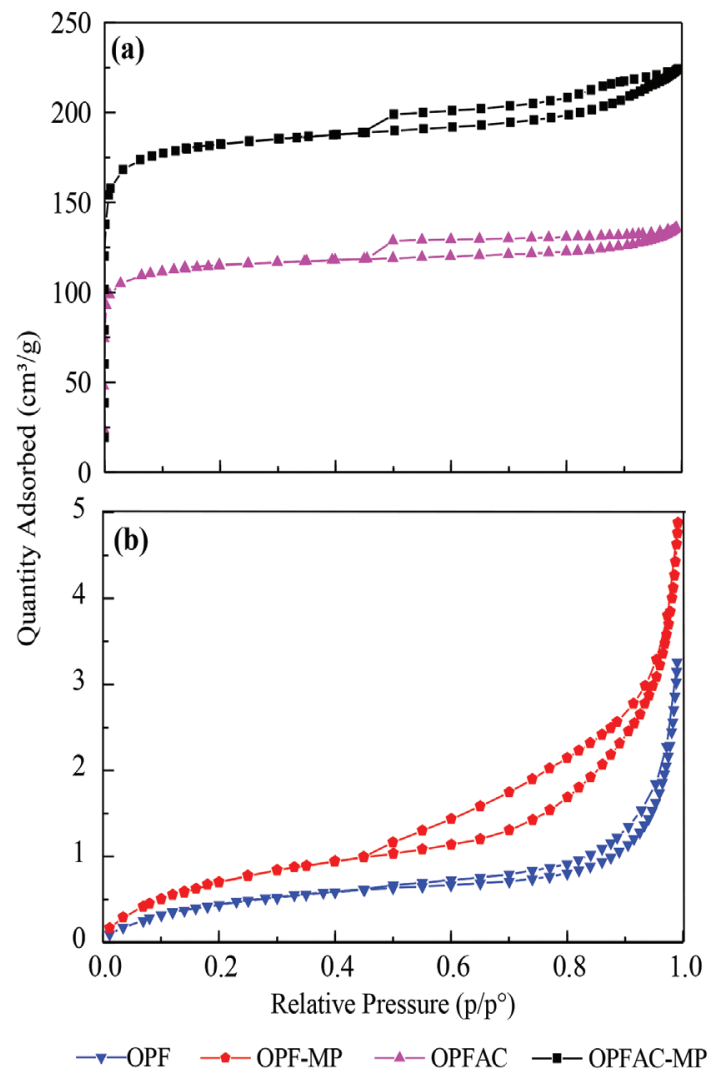

FIGURE 4. Nitrogen sorption isotherms of (a) OPFAC and OPFAC-MP and (b) OPF and OPF-MP

due to pore blocking. However, some previous studies reported an increase in the surface area of parent material after impregnation (Hu et al. 2011; Panneerselvam et al. 2011; Zainol et al. 2014). This is possibly due to high dispersion of magnetic particles with a specific surface area on the material surface. The high dispersion of magnetic particles on the surface sample may influence the increasing of surface area of modified adsorbent. Since the magnetic particles may have their specific surface area, thus, this contributes to the increasing of total surface area of magnetic adsorbent compared to parent material. Park et al. (2011) has synthesized magnetic particles using three different methods and the results were shown that magnetic

TABLE 2. Surface area, pore volume and pore diameter of OPF-MP, OPFAC-MP and their parent samples

\begin{tabular}{lccccccc}
\hline \multirow{2}{*}{ Sample } & \multicolumn{3}{c}{ Surface area $\left(\mathrm{m}^{2} / \mathrm{g}\right)$} & \multicolumn{2}{c}{ Volume $\left(\mathrm{cm}^{3} / \mathrm{g}\right)$} & \multicolumn{2}{c}{ Diameter $(\mathrm{nm})$} \\
\cline { 2 - 7 } & Total & Micro & Meso & Micro & Meso & Micro & Meso \\
\hline $\begin{array}{l}\text { Parent materials } \\
\text { OPF }\end{array}$ & 1.91 & n.a & 1.91 & n.a & 0.005 & n.a & 8.77 \\
$\quad$ OPFAC & 440 & 368 & 72 & 0.15 & 0.05 & 0.60 & 4.21 \\
Magnetic adsorbents & & & & & & & \\
$\quad$ OPF-MP & 2.94 & n.a & 2.94 & n.a & 0.008 & n.a & 8.96 \\
$\quad$ OPFAC-MP & 700 & 590 & 110 & 0.23 & 0.09 & 0.72 & 5.13 \\
\hline
\end{tabular}

n.a - not available 
particles have obtained their surface area. Besides, there is possibility that the parent material have been treated with the precipitation of the iron oxide (Zainol et al. 2014). The heating process by the metal solution may give some effect on the pore structure and surface area. The pore diameter was increased after the impregnation proses, thus increasing their pore volume and surface area. From the result, OPFAC-MP shows that impregnation with magnetic particles on the parent material has given a significant increase in surface area.

Study of phase structure The XRD pattern show the diffraction peaks characteristic of parent materials and magnetic phase of impregnated materials (Figure 5). The formation of amorphous phase of carbon was presented by OPFAC at $2 \theta$ of $10^{\circ}$ to $30^{\circ}$. At the same range of $2 \theta$, OPF sample has shown a diffraction peak crystal structure of cellulose together with formation of amorphous phase of lignin. The chemical activation of OPF has decomposed organic compounds during the carbonization. The restructuring of carbon bonding was occurs and lead to formation of amorphous phase structure. The amorphous carbon with a complex arrangement of structure was oriented with random aromatic carbon arrangement (Hara 2010; Okamura et al. 2006; Zainol et al. 2015).

New diffraction peaks for magnetic phase are shown by magnetic adsorbents compared to the parent materials. The magnetic phase referred to the formation of magnetite $\left(\mathrm{Fe}_{3} \mathrm{O}_{4}\right)$ and maghemite $\left(\gamma-\mathrm{Fe}_{2} \mathrm{O}_{3}\right)$. Tural et al. (2009), was stated that $\mathrm{Fe}_{3} \mathrm{O}_{4}$ or $\gamma-\mathrm{Fe}_{2} \mathrm{O}_{3}$ are usually used as magnetic materials (Tural et al. 2009). Both iron oxides were accepted to magnetize parent materials since both are having magnetic phase. Sharp peak for magnetic phase were observed through OPFAC-MP samples but for OPF-MP, the only small intensity of diffraction peak for magnetic phase was observed. The less dispersion or impregnated of the magnetic particles on OPF becomes the factor of the small diffraction peak of magnetic phase detection. Less surface area of OPF possibly affects the impregnation process which reduces the dispersion of magnetic particles and intensity of XRD diffraction peaks. High dispersion of magnetic particles on high surface area of OPFAC-MP makes the detection of magnetic phase can be observed. The detection of magnetic phase through XRD analysis was shown that the magnetic particles were impregnated on parent materials. This result, were consistent with the FESEM images that shows high dispersion of magnetic particle on surface of OPFAC compared to OPF.

Magnetization behaviour Magnetic adsorbent has showed some magnetic properties through analysis using VSM (Figure 6). The curve was used to indicate the magnetic behaviour with the present of the hysteresis loop. Based on the magnetization curve, the plot was increased with increasing of the field strength until approached magnetic saturation. Ideal superparamagnetic behaviour was presented without hysteresis loop. The hysteresis loop forms when magnetic fields were reduced and form a different curve. If the hysteresis loop occurs (Figure 6(a)), there is present magnetization amount called remanence when the magnetization is offset from origin at zero external magnetic fields. Consequently, the coercivity forms which explained the intensity of applied magnetic field required to reduce the magnetization value to zero.

Based on the result (Figure 6(b)), there is very small coercivity and remanent presents for OPF-MP and OPFACMP. The samples have achieved saturated magnetization value of 2.36 and $2.76 \mathrm{emu} / \mathrm{g}$, respectively. High magnetization value of OPFAC-MP was influenced by high dispersion of magnetic particles on the surface due to high surface area. Thus, OPFAC-MP had achieved high magnetization value compared to OPF-MP.

A very small hysteresis was presented due to very small coercivity and remanence value. Accordingly, it was suggested that OPF-MP and OPFAC-MP have superparamagnetic behavior. Possibilities of the aggregation of magnetic particles, the product resulted in small remanence and coercivity with nanoparticles size are expected to be superparamagnetic (Tural et al. 2009).
Parent material

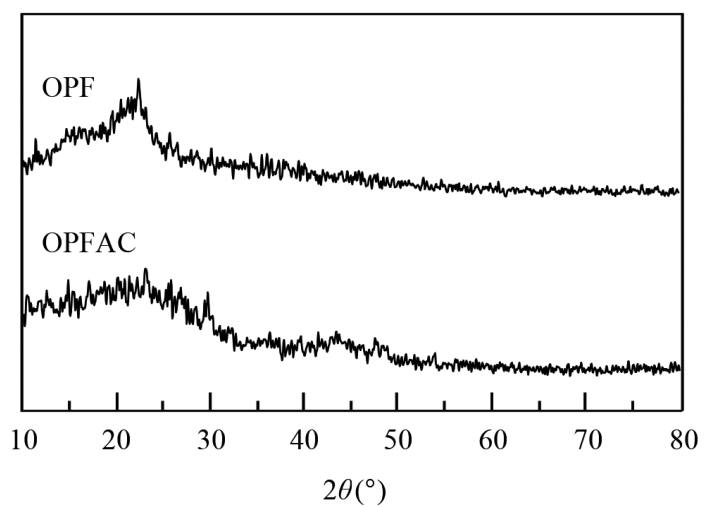

Magnetic adsorbent

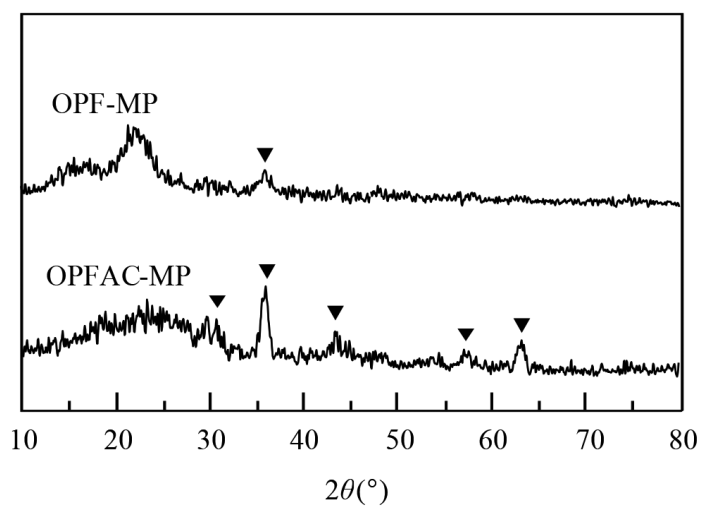

FIGURE 5. XRD patterns of parent materials and magnetic adsorbents. Invert solid triangle, magnetic phase 


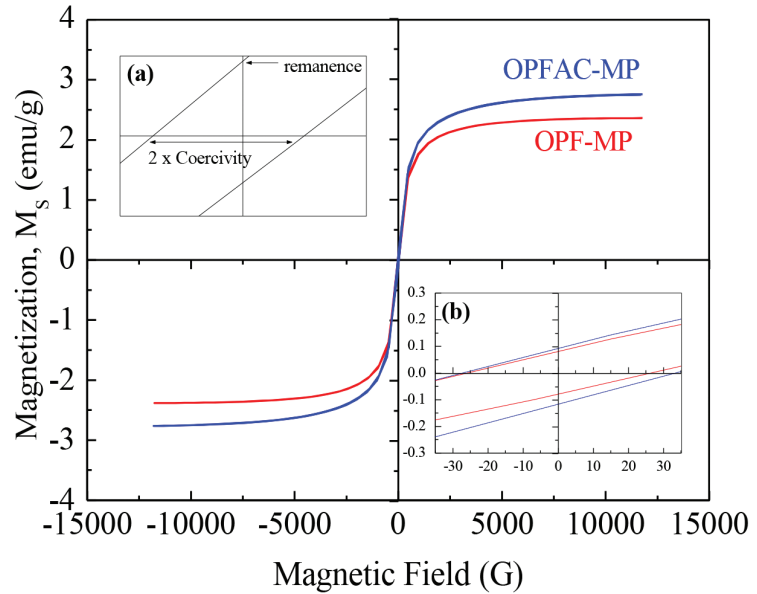

FIGURE 6. Magnetization curve of OPF-MP and OPFAC-MP. (a)

Remanence and coercivity of hysteresis loop and (b) small remanence and coercivity value of magnetic adsorbents

\section{HEAVY METAL IONS ADSORPTION}

Zero point charge $\left(\mathrm{pH}_{z p c}\right)$ Zero point charge $\left(\mathrm{pH}_{\mathrm{zpc}}\right)$ is one alternative to determine the optimum $\mathrm{pH}$ value for adsorption study. Figure 7 shows the $\mathrm{pH}_{\mathrm{zpc}}$ of OPF-MP and OPFAC-MP are 6.04 and 7.41, respectively. These points suggested that the $\mathrm{pH}$ condition may possibly contribute in achieving higher removal and above this point there may be no significant change in adsorption after equilibrium is achieved. As stated by Panneerselvam et al. (2011), the $\mathrm{pH}_{\mathrm{zpc}}$ indicates the electrical neutrality of adsorbent surface to achieve optimum removal (Panneerselvam et al. 2011). Further study was conducted for adsorption of metal ions at different $\mathrm{pH}$ value to discuss the metal ions removal by these magnetic adsorbents.

Removal and Adsorption of $\mathrm{Pb}(\mathrm{II}), \mathrm{Zn}(\mathrm{II}), \mathrm{Cu}(\mathrm{II}) \quad$ The adsorption of metal ions was investigated to observe the ability and efficiency of the magnetic adsorbents in metal ions removal. Based on Figure 8, the removals efficiency has increases gradually up to $\mathrm{pH} 4$ for all metal ions

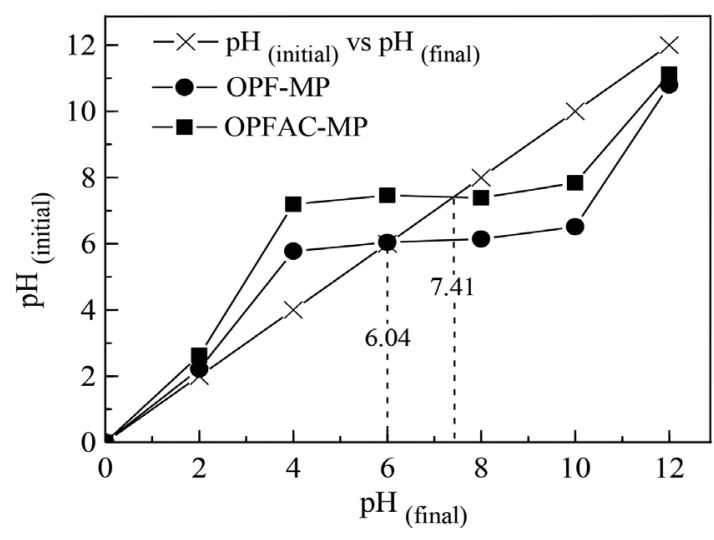

FIGURE 7. Plot for determination of point zero charge of OPF-MP and OPFAC-MP

and almost constant after the pH6 for $\mathrm{Pb}(\mathrm{II}), \mathrm{Zn}$ (II) and $\mathrm{Cu}(\mathrm{II})$ ions. Higher removal of metal ions was achieved using OPF-MP with removal efficiencies more than $71 \%$. However, good performance was demonstrated by OPFACMP in achieving high removal of $\mathrm{Pb}(\mathrm{II}), \mathrm{Zn}$ (II) and $\mathrm{Cu}$ (II) ions up to $100 \%, 93 \%$ and $99 \%$, respectively. OPFAC-MP has shown good removal for these three metal ions with a small adsorbent dosage of $0.1 \mathrm{~g}$ compared to OPF-MP with $0.15 \mathrm{~g}$ of dosage. The adsorption process usually may achieve higher removal efficiency by using high dosage of adsorbent. However, the high dosage may increase the treatment cost and reduce the overall process efficiency. Thus, the adsorption capacity needs to be considered in the selection of adsorbent.

The adsorption capacities between the magnetic adsorbents were compared at different $\mathrm{pH}$ value as shown in Figure 9. OPFAC-MP shows high adsorption capacity (above pH6) of $\mathrm{Pb}$ (II), $\mathrm{Zn}$ (II) and $\mathrm{Cu}(\mathrm{II})$ ions up to 15.0 , 13.9 and $14.9 \mathrm{mg} / \mathrm{g}$, respectively. As for OPF-MP, the adsorption capacities of metal ions were in the range $6.9-9.2 \mathrm{mg} / \mathrm{g}$. The low density material of OPF-MP and OPFAC-MP gives a benefit on their adsorption capacity. From previous study, the oil palm shell activated carbon

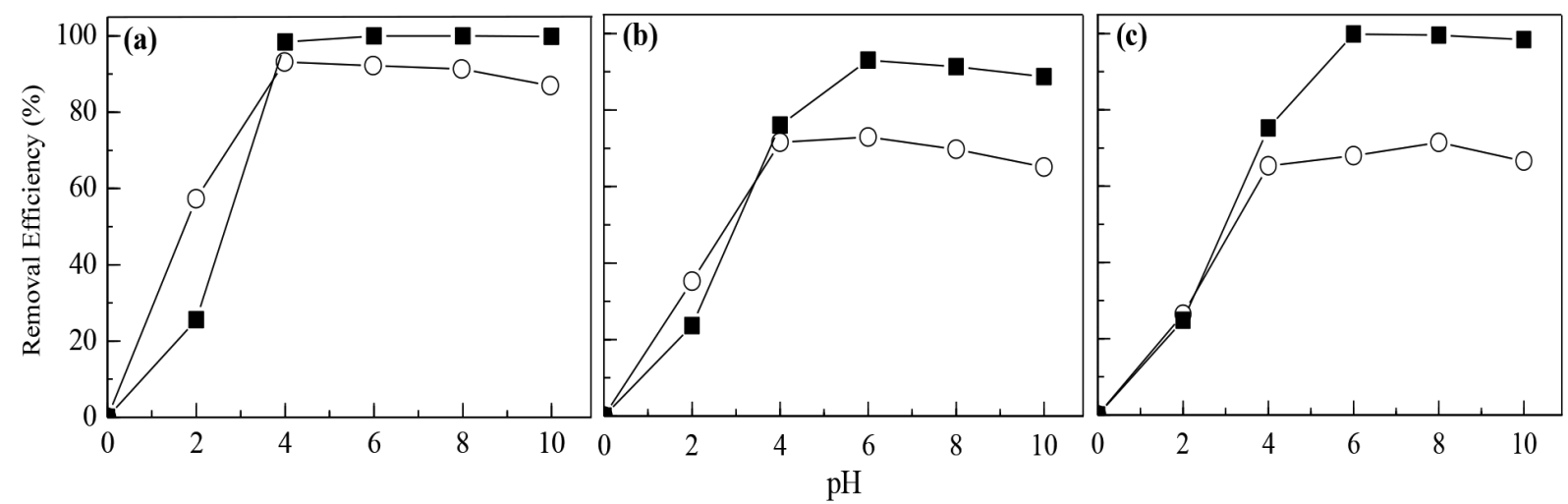

FIGURE 8. Removal efficiency of (a) Pb(II), (b) $\mathrm{Zn}$ (II) and (c) $\mathrm{Cu}$ (II) ions by $0.15 \mathrm{~g}$ OPF-MP (O), and $0.1 \mathrm{~g}$ OPFAC-MP $(\square)$ at $30 \mathrm{mg} / \mathrm{L}$ and $30 \mathrm{~min}$ 


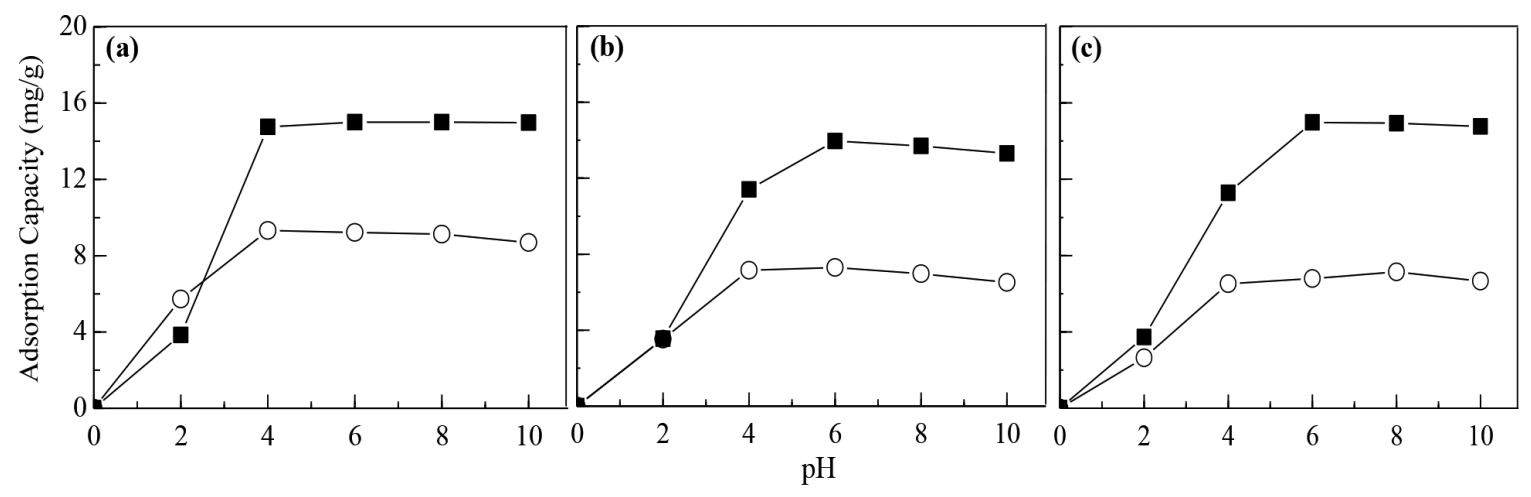

FIGURE 9. Adsorption capacity of (a) $\mathrm{Pb}(\mathrm{II})$, (b) $\mathrm{Zn}$ (II) and (c) $\mathrm{Cu}$ (II) ions by $0.15 \mathrm{~g}$ OPF-MP (O) and $0.1 \mathrm{~g}$ OPFAC-MP $(\square)$ at $30 \mathrm{mg} / \mathrm{L}$ and $30 \mathrm{~min}$

magnetic particle (CAC-MP) only achieved adsorption capacity of $2.2-2.8 \mathrm{mg} / \mathrm{g}$ towards ions removal although high removal efficiency was achieved (Zainol et al. 2014). This is possibly due to high density of CAC-MP compared to OPF-MP and OPFAC-MP. CAC-MP required high dosage of adsorbent for high removal efficiency which reduced their adsorption capacity. Accordingly, OPFAC-MP has good adsorption on $\mathrm{Pb}(\mathrm{II}), \mathrm{Zn}(\mathrm{II})$ and $\mathrm{Cu}(\mathrm{II})$ ions compared to OPF-MP. OPFAC-MPalso show good performance in removal of $\mathrm{Cu}$ (II) ions compared to OPF-MP that better in removing $\mathrm{Pb}$ (II) ions rather than $\mathrm{Cu}$ (II) ions .

As stated earlier, the removal possibly achieves equilibrium above the $\mathrm{pH}_{\mathrm{zpc}}$. Through the study of adsorption at different $\mathrm{pH}$, the result shows no significant change of removal efficiency and adsorption capacity above the $\mathrm{pH}_{\mathrm{zpc}}$. The adsorption was influenced by the solution condition ( $\mathrm{pH}$ value) to attract the metal ions on adsorbent surface via electrostatic force between the metal ions and anions. The carboxyls of adsorbents are presents at low $\mathrm{pH}$. As the alkalinity of solution increases, the carboxyls may turn into carboxylate anions and reached optimum pH as all carboxyl have turned into carboxylate anions. Therefore, the adsorption increased when the $\mathrm{pH}$ value of the solution increased up to the optimum. No more changes in metal ions removal was observed after the carboxyls completely turned into carboxylate anions (Ge et al. 2012). The concentration of $\mathrm{H}^{+}$ions was high at lower $\mathrm{pH}$ which caused low removal efficiency due to the competition between the metal ions with $\mathrm{H}^{+}$ions on the vacant adsorbent site (Panneerselvam et al. 2011). The electrostatic force between the carboxylate anions and the metal ions leads to the precipitation of metal ions on the adsorbent.

Comparative study and potential analysis The comparative studies on the removal and adsorption of metals ions by the magnetic adsorbents and their parent materials were depicted in the Figure 10. Based on Figure 10(a), OPFACMP achieved 93.1-100.0\% of $\mathrm{Pb}(\mathrm{II}), \mathrm{Zn}(\mathrm{II})$ and $\mathrm{Cu}(\mathrm{II})$ ions removal as compared to OPFAC with $80.1-96.0 \%$ of ions removed. Impregnation of magnetic particles enhances removal efficiency and this tendency was more obvious in OPF-MP. OPF-MP presents removal efficiency of 68.0$92.2 \%$ contrasted to OPF with $35.3-43.1 \%$ of metal ions. These results suggested high removal were achieved by the magnetic adsorbents compared to their parent materials.

The results of their adsorption capacity were presented in Figure 10(b) in order to compare the performance between the adsorbents. In general, the impregnation of magnetic particles on the OPF and OPFAC enhanced the metal

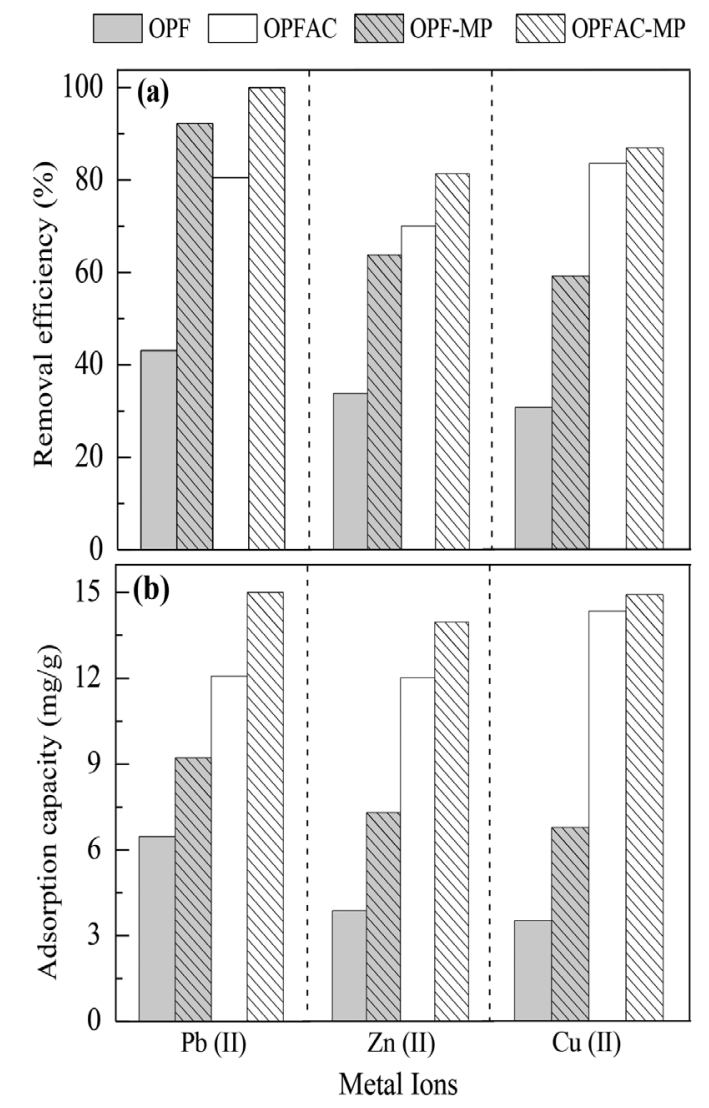

FIGURE 10. Removal efficiency and adsorption capacity of $\mathrm{Pb}(\mathrm{II}), \mathrm{Zn}(\mathrm{II})$, and $\mathrm{Cu}(\mathrm{II})$ ions by $0.15 \mathrm{~g}$ OPF and OPF-MP and $0.1 \mathrm{~g}$ OPFAC and OPFAC-MP at $\mathrm{pH} 6,30 \mathrm{mg} / \mathrm{L}$ and $30 \mathrm{~min}$ 
TABLE 3. Potential analysis of adsorbents for metal ions removal based on removal efficiency and adsorption capacity

\begin{tabular}{|c|c|c|c|c|c|c|}
\hline \multirow{2}{*}{ Sample } & \multicolumn{3}{|c|}{ Removal efficiency } & \multicolumn{3}{|c|}{ Adsorption capacity } \\
\hline & $\mathrm{Pb}(\mathrm{II})$ & $\mathrm{Zn}(\mathrm{II})$ & $\mathrm{Cu}(\mathrm{II})$ & $\mathrm{Pb}(\mathrm{II})$ & $\mathrm{Zn}(\mathrm{II})$ & $\mathrm{Cu}(\mathrm{II})$ \\
\hline OPF & - & - & - & + & + & + \\
\hline OPF-MP & ++ & + & + & + & + & + \\
\hline OPFAC & + & + & ++ & ++ & ++ & ++ \\
\hline OPFAC-MP & ++ & ++ & ++ & ++ & ++ & ++ \\
\hline
\end{tabular}

ions adsorption. Low adsorption capacity of $\mathrm{Pb}(\mathrm{II}), \mathrm{Zn}(\mathrm{II})$ and $\mathrm{Cu}$ (II) ions were performed by OPF $(3.5-6.5 \mathrm{mg} / \mathrm{g}$ ) and OPF-MP (6.8-9.2 mg/g) compared to other adsorbents. Interestingly, high adsorption capacity was achieved by OPFAC and OPFAC-MP. The OPFAC has capability to adsorb about $12.0-14.4 \mathrm{mg} / \mathrm{g}$ of $\mathrm{Pb}(\mathrm{II}), \mathrm{Zn}$ (II) and $\mathrm{Cu}(\mathrm{II})$ ions, while adsorption by OPFAC-MP was achieved about 15.0, 14.0 and $15.0 \mathrm{mg} / \mathrm{g}$, respectively. This results showed that OPFAC and OPFAC-MP displays high potential in adsorption of $\mathrm{Pb}(\mathrm{II}), \mathrm{Zn}(\mathrm{II})$ and $\mathrm{Cu}(\mathrm{II})$ ions.

As for further discussion, the results represent in Table 3 was tabulated (based on result in Figure 10) for qualitative analysis on the potential of adsorbents in removing metal ions and comparison on their adsorption capacity. Through the analysis, the OPF shows low removal of metal ions compared to OPF-MP. OPF-MP shows high potential to remove $\mathrm{Pb}$ (II) ions compared to $\mathrm{Zn}$ (II) and $\mathrm{Cu}(\mathrm{II})$ ions. The activation of OPF to produce OPFAC shows the high potential of OPFAC in removing $\mathrm{Cu}$ (II) ions. The impregnation of magnetic particles on OPFAC has improved their metal ions adsorption. Consequently, OPFAC-MP has shown high potential in removing $\mathrm{Pb}$ (II), $\mathrm{Zn}$ (II) and $\mathrm{Cu}$ (II) metal ions.

\section{CONCLUSION}

The magnetic particles have successfully impregnated on the OPF and OPFAC via co-precipitation method. High surface areas of OPFAC-MP have been produced with magnetic properties. The good surface chemistry of magnetic adsorbents and their parent's materials has influenced the metal ions removal on the adsorbents surface. The impregnation of magnetic particles enhances the metal ions adsorption comparing to their parent's material. OPFAC-MP has shown high removal $(\sim 100 \%)$ and adsorption capacity (up to $15.0 \mathrm{mg} / \mathrm{g}$ ) of $\mathrm{Pb}$ (II), $\mathrm{Zn}$ (II) and $\mathrm{Cu}(\mathrm{II})$ ions compared to OPF-MP.

\section{ACKNOWLEDGEMENTS}

We are grateful for the financial support via project under Research University Grant (vote 04H69) and Fundamental Research Grant Scheme (vote 4F160) by the Ministry of Higher Education (MOHE), Malaysia and Universiti Teknologi Malaysia (UTM).

\section{REFERENCES}

AbdurRahman, F.B., Akter, M. \& Abedin, M.Z. 2013. Dyes removal from textile wastewater using orange peels. Int. J. Sci.Technol. Res. 2: 2277-8616.

Alam, Z., Muyibi, S.A. \& Toramae, J. 2007. Statistical optimization of adsorption processes for removal of 2,4-dichlorophenol by activated carbon derived from oil palm empty fruit bunches. Journal of Environmental Sciences 19(6): 674-677.

Bulut, Y.\& Tez,Z. 2007. Removal of heavy metals from aqueous solution by sawdust adsorption. Journal of Environmental Sciences 19(2): 160-166.

Chang, Y.C. \& Chen, D.H. 2005. Preparation and adsorption properties of monodisperse chitosan-bound $\mathrm{Fe} 3 \mathrm{O} 4$ magnetic nanoparticles for removal of $\mathrm{Cu}$ (II) ions. Journal of Colloid and Interface Science 283: 446-451.

Chen, Y., Huang, B., Huang, M. \& Cai, B. 2011. On the preparation and characterization of activated carbon from mangosteen shell. Journal of the Taiwan Institute of Chemical Engineers 42(5): 837-842.

Chertoka, B., Moffatb, B.A., Davida, A.E., Yua, F., Bergemannc, C., Rossb, B.D.\& Yanga, V.C. 2008. Iron oxide nanoparticles as a drug delivery vehicle for MRI monitored magnetic targeting of brain tumors. Biomaterials 29: 487-496.

Chia, C.H., Razali, N.F., Sajab, M.S., Zakaria, S., Huang, N.M. \& Lim, H.N. 2013. Methylene blue adsorption on graphene oxide. Sains Malaysiana 42(6): 819-826.

Ding, S., Xing, Y., Radosz, M. \& Shen, Y. 2006. Magnetic nanoparticle supported catalyst for atom transfer radical polymerization. Macromolecules 39(6399-6405).

Donia, A.M., Atia, A.A. \& Abouzayed, F.I. 2012. Preparation and characterization of nano-magnetic cellulose with fast kinetic properties towards the adsorption of some metal ions. Chemical Engineering Journal 191(0): 22-30.

Gao, Y., Yue, Q., Gao, B., Sun, Y., Wang, W., Li, Q. \& Wang, Y. 2013. Preparation of high surface area-activated carbon from lignin of papermaking black liquor by $\mathrm{KOH}$ activation for Ni(II) adsorption. Chemical Engineering Journal 217: 345-353.

Ge, F., Li, M.M., Ye, H. \& Zhao, B.X. 2012. Effective removal of heavy metal ions $\mathrm{Cd}^{2+}, \mathrm{Zn}^{2+}, \mathrm{Pb}^{2+}, \mathrm{Cu}^{2+}$ from aqueous solution by polymer-modified magnetic nanoparticles. Journal of Hazardous Materials 211-212(0): 366-372.

Gill, C.S., Price, B.A. \& Jones, C.W. 2007. Sulfonic acidfunctionalized silica-coated magnetic nanoparticle catalysts. Journal of Catalysis 251: 145-152.

Guo, X., Zhang, S. \& Shan, X.Q. 2008. Adsorption of metal ions on lignin. Journal of Hazardous Materials 151(1): 134-142. 
Gurten,I.I., Ozmak, M., Yagmur,E. \& Aktas, Z. 2012.Preparation and characterisation of activated carbon from waste tea using K2CO3. Biomass and Bioenergy 37(0): 73-81.

Hara, M. 2010. Biodiesel production by amorphous carbon bearing $\mathrm{SO}_{3} \mathrm{H}, \mathrm{COOH}$ and phenolic $\mathrm{OH}$ groups, a solid brønsted acid catalyst. Topics in Catalysis 53(11-12): 805810.

Hu, S., Guan, Y., Wang, Y. \& Han, H. 2011. Nano-magnetic catalyst $\mathrm{KF} / \mathrm{CaO}-\mathrm{Fe}_{3} \mathrm{O}_{4}$ for biodiesel production. Applied Energy 88(8): 2685-2690.

Hua, M.Y., Yang, H.W., Chuang, C.K., Tsai, R.Y., Chen, W.J., Chuang, K.L., Chang, Y.H., Chuang, H.C. \& Pang, S.T. 2010. Magnetic-nanoparticle-modified paclitaxel for targeted therapy for prostate cancer. Biomaterials 31: 7355-7363.

Kaşgöz, H., Özgümüş, S. \& Orbay, M. 2003. Modified polyacrylamide hydrogels and their application in removal of heavy metal ions. Polymer 44(6): 1785-1793.

Liao, M.H. \& Chen, D.H. 2002 . Preparation and characterization of a novel magnetic nano-adsorbent. Journal of Materials Chemistry 12: 3654-3659.

Liu, C., Lv, P., Yuan, Z., Yan, F. \& Luo, W. 2010. The nanometer magnetic solid base catalyst for production of biodiesel. Renewable Energy 35(7): 1531-1536.

Malik, P. 2004. Dye removal from wastewater using activated carbon developed from sawdust: Adsorption equilibrium and kinetics. Journal of Hazardous Materials 113(1): 81-88.

Mornet, S.P., Vasseur, S.B., Grasset, F. \& Duguet, E. 2004. Magnetic nanoparticle design for medical diagnosis and therapy. J. Mater. Chem. 14: 2161-2175.

Okamura, M., Takagaki, A., Toda, M., Kondo, J.N., Domen, K., Tatsumi, T., Hara, M. \& Hayashi, S. 2006. Acid-catalyzed reactions on flexible polycyclic aromatic carbon in amorphous carbon. Chemistry of Materials 18(13): 3039-3045.

Oliveira, L.C.A., Rios, R.V.R.A., Fabris, J.D., Garg, V., Sapag, K. \& Lago, R.M. 2002. Activated carbon/iron oxide magnetic composites for the adsorption of contaminants in water. Carbon 40(12): 2177-2183.

Panneerselvam, P., Morad, N. \& Tan, K.A. 2011. Magnetic nanoparticle $\left(\mathrm{Fe}_{3} \mathrm{O}_{4}\right)$ impregnated onto tea waste for the removal of nickel(II) from aqueous solution. Journal of Hazardous Materials 186(1): 160-168.

Park, H.J., McConnell, J.T., Boddohi, S., Kipper, M.J. \& Johnson, P.A. 2011. Synthesis and characterization of enzymemagnetic nanoparticle complexes: Effect of size on activity and recovery. Colloids and Surfaces B: Biointerfaces 83(2): 198-203.

Perez, J.M., O’Loughin, T., Simeone, F.J., Weissleder, R. \& Josephson, L. 2002. DNA-based magnetic nanoparticle assembly acts as a magnetic relaxation nanoswitch allowing screening of DNA-cleaving agents. Journal of the American Chemical Society 124(12): 2856-2857.

Poljanšek, I. \& Krajnc, M. 2005. Characterization of phenolformaldehyde prepolymer resins by in line FT-IR spectroscopy. Acta Chimica Slovenica 52(0): 238-244.
Rudge, S.R., Kurtz, T.L., Vessely, C.R., Catterall, L.G. \& Williamson, D.L. 2000. Preparation, characterization, and performance of magnetic iron-carbon composite microparticles for chemotherapy. Biomaterials 21: 14111420 .

Stoeva, S.I., Huo, F., Lee, J.S. \& Mirkin, C.A. 2005. Three-layer composite magnetic nanoparticle probes for DNA. Journal of the American Chemical Society 127(44): 15362-15363.

Tural, B., Özkan, N. \& Volkan, M. 2009. Preparation and characterization of polymer coated superparamagnetic magnetite nanoparticle agglomerates. Journal of Physics and Chemistry of Solids 70(5): 860-866.

Vu, T.A., Le, G.H., Dao, C.D., Dang, L.Q., Nguyen, K.T., Nguyen, Q.K., Dang, P.T., Tran, H.T., Duong, Q.T. \& Nguyen, T.V. 2015. Arsenic removal from aqueous solutions by adsorption using novel MIL-53 (Fe) as a highly efficient adsorbent. RSC Advances 5(7): 5261-5268.

Xu, F., Yu, J., Tesso, T., Dowell, F. \& Wang, D. 2013. Qualitative and quantitative analysis of lignocellulosic biomass using infrared techniques: A mini-review. Applied Energy 104: 801-809.

Yaacob, W.Z.W. \& Samsudin, A.R. 2007. Sorption parameters of $\mathrm{Pb}$ and $\mathrm{Cu}$ on natural clay soils from Selangor, Malaysia. Sains Malaysiana 36(2): 149-157.

Yao, S., Liu, Z. \& Shi, Z. 2014. Arsenic removal from aqueous solutions by adsorption onto iron oxide/activated carbon magnetic composite. J. Environ. Health Sci. Eng. 12: 1-8.

Yao, Y., Miao, S., Liu, S., Ma, L.P., Sun, H. \& Wang, S. (2012). Synthesis, Characterization, and Adsorption Properties of Magnetic Fe3O4@Graphene Nanocomposite.Chemical Engineering Journal 184(0): 326-332.

Zainol, M.M., Amin, N.A.S. \& Asmadi, M. 2015. Synthesis and characterization of carbon cryogel microspheres from lignin-furfural mixtures for biodiesel production. Bioresource Technology 190(0): 44-50.

Zainol, M.M., Asmadi, M. \& Amin, N.A.S. 2014. Impregnation of magnetic particles on oil palm shell activated carbon for removal of heavy metal ions from aqueous solution. Jurnal Teknologi 72(1): 7-11.

Chemical Reaction Engineering Group (CREG)

Faculty of Chemical and Energy Engineering

Universiti Teknologi Malaysia

81300 UTM Skudai, Johor Darul Takzim

Malaysia

*Corresponding author; email: noraishah@cheme.utm.my

Received: 19 July 2016

Accepted: 24 October 2016 